\title{
A NOTE ON THE REVISED TEXT
}

These poems for the revised edition of Shadowed Dreams first appeared in journals of the New Negro Movement or in anthologies and collections from the period. The journals include The Crisis, founded by the National Association for the Advancement of Colored People (NAACP) in 1910 and edited by W.E.B. Du Bois; Opportunity, established by the National Urban League in 1923 and edited by Charles S. Johnson; The Messenger, spanning the years 1917-1928 and edited by A. Philip Randolph and Chandler Owen; the single issue of Fire!! edited by Wallace Thurman in November 1926; The Saturday Evening Quill, founded by a group of African American writers in Boston (1928-1930) and edited by Eugene Gordon; a special issue of Palms edited by Countée Cullen in 1926; Black Opals, a short-lived 1927 journal edited by Arthur Huff Fauset in Philadelphia; and Challenge, edited by Dorothy West from 1934 to 1937. Material from Negro World, published by Marcus Garvey's Universal Negro Improvement Association from 1918 to 1933, is not represented because so little poetry by black women appears in its pages.

Anthologies of the day include James Weldon Johnson's The Book of American Negro Poetry (1922, 1931); Robert T. Kerlin's Negro Poets and Their Poems (1923); Alain Locke's touchstone text The New Negro (1925); the National Urban League's Ebony and Topaz (1927); Countée Cullen's ground-breaking Caroling Dusk (1927); Readings from Negro Authors, edited by Otelia Cromwell, Lorenzo Dow Turner, and Eva B. Dykes (1931); Victor Calverton's An Anthology of American Negro Literature (1929); William Stanley Braithwaite's Anthology of Magazine Verse (1927, 1928); and Beatrice M. Murphy's Negro Voices (1938). These are anthologies in which significant numbers of poems by women appear and which arguably were the most influential.

Although relatively few poetry collections were published by women, those that were furnished the remaining material for this volume: Georgia Douglas Johnson's The Heart of a Woman and Other Poems (1918), Bronze: A Book of Verse (1922), and An Autumn Love Cycle (1928); Sarah Lee Brown Fleming's Clouds and Sunshine (1920); Carrie Williams Clifford's The Widening Light (1922); Sarah Collins 
Fernandis's Poems (1925); Clara Ann Thompson's A Garland of Poems (1926); Mae V. Cowdery's We Lift Our Voices and Other Poems (1936); Lucy Mae Turner's 'Bout Culled Folkses (1938); Anita Scott Coleman's Small Wisdom (1937); Esther Popel's A Forest Pool (1934); and Ida Rowland's Lisping Leaves (1939). These are not all the collections published by women of the Harlem Renaissance (those published after 1940 are not included), but most of them are represented here.

All publication venues of a particular poem are listed in order of appearance to indicate how well distributed it was. The only changes that have been made to the original pieces are silent corrections of typographical, spelling, and punctuation errors or lengthening of lines that were obviously limited by the width of columns in the original typescript.

The selection process was governed by a number of factors. One of these was that I wanted to represent all the major poets with a good number of pieces, their lesser-known works as well as those that have been reprinted, in order to give a sense of their range. I felt it was important, too, to include writers who never made it into the major anthologies or journals. Most women had neither the resources nor social contacts to compile a significant body of work, and many remained outside Harlem Renaissance publishing networks, yet they played a key role in the cultural awakening within African American communities of the time while suggesting their broadly based nature. Artistic value was another factor I considered in making the final selection. Admittedly relying on subjective judgment, I looked for pieces that have held up over time and that contain striking metaphors or well-composed lines to underscore the contemporary as well as historical value of this poetry. I eliminated, for instance, verse that seemed to me derivative or awkwardly rendered. Finally, I chose poems representative of the subjects and themes that appear most frequently during this period and provide a glimpse into the concerns and sensibility of the Renaissance generation. These poems reverberate with notes commonly struck, and their meaning is enriched by the threads that weave them together. This literary generation shared a voice as well as a historical era.

Finally, it should be noted that during the Harlem Renaissance, journals published poetry by many white writers without identifying 
their ethnicity. In the case of those poets in this anthology for whom I could not find biographical information, therefore, it is possible that they are not African Americans. As we retrieve more information about women writers from the past, we will, I hope, be able to more accurately attribute authorship to women of color. 
Oh Magalu, come! Take my hand and I will read you poetry...

—Helene Johnson, "Magalu” (1927) 


\section{shadowed \\ Dreams}


